\title{
EFFECT OF LIMING ON THE FATE OF APPLIED SUPERPHOS- PHATE PHOSPHORUS IN SOME MINERAL SOILS
}

\author{
Armi KaIla \\ University of Helsinki, Department of Agricultural Chemistry
}

Received November 28, 1966

In previous papers (KAILA 1961, 1965a), the author reported results on the effect of liming on the distribution of soil phosphorus in various fractions. It was found that the relatively heavy treatment with $\mathrm{CaCO}_{3}$ in incubation experiments affected, in the first place, the inorganic phosphorus, increasing the fluoride-soluble and acid-soluble forms of the CHANG and JAckson (1951) fractionation at the expense of the alkali-soluble fraction: in most cases, the accelerative effect on the mineralisation of organic phosphorus was not significant.

Studies on the fate of applied soluble phosphate in soils (KAILA 1963a, 1965a) showed that both in the field and in incubation experiments in the laboratory the phosphate treatment of most soils increased markedly only the phosphorus fractions extracted by $\mathrm{NH}_{4} \mathrm{~F}$ and $\mathrm{NaOH}$. The part of applied phosphorus recovered in the fluoride soluble form tended to be the higher and that recovered in the alkali-soluble form the lower, the higher was the amount of phosphate applied. On the other hand, the soils seem to have a characteristic pattern of phosphate retention which in extreme cases may mean an almost complete sorption of the applied phosphate as either the fluoride-soluble or the alkali-soluble forms, though usually the distribution between these two fractions appears to be more equal.

In the present work an attempt is made to study the effect of lime on the fate of superphosphate phosphorus, when both are applied simultaneously. Particular attention is paid to the possibilities of lime to disturb the phosphorus distribution pattern typical of the soil.

\section{Material and methods}

Samples from the plough layer of a silt soil, loam soil, and a clay loam soil, and from the depth of 20 to $40 \mathrm{~cm}$ of a virgin sandy clay soil were used in the present study. The samples were air-dried and ground to pass a $2 \mathrm{~mm}$ sieve. 
The fractionation of soil phosphorus was performed by the method of $\mathrm{CHANG}_{\mathrm{H}}$ and JACKSON (1951); instead of neutral $\mathrm{NH}_{4} \mathrm{~F}$ a slightly alkaline extractant was used. The total phosphorus content was determined by the sodium carbonate fusion method (MUIR 1952). The organic phosphorus content was estimated as an average of the results obtained by the author's ignition method and extraction method (KaILA 1962). The indicator of the phosphate sorption capacity, $\mathrm{k}$, was calculated on the basis of the Freundlich adsorption isotherm (KAILA 1963b).

Table 1. Soil samples

\begin{tabular}{|c|c|c|c|c|c|c|c|}
\hline \multirow[b]{2}{*}{ Kind of soil } & \multirow[b]{2}{*}{$\mathrm{pH}$} & \multirow{2}{*}{$\begin{array}{c}\text { Org. C } \\
\%\end{array}$} & \multicolumn{3}{|c|}{ Mechanical fractions \% } & \multirow{2}{*}{$\begin{array}{c}\mathrm{Al} \\
\mathrm{ppm}\end{array}$} & \multirow{2}{*}{$\begin{array}{c}\mathrm{Fe} \\
\mathrm{ppm}\end{array}$} \\
\hline & & & $<2 \mu$ & $2-20 \mu$ & $20-200 \mu$ & & \\
\hline 1. Silt & 4.6 & 2.1 & 18 & 52 & 27 & 2330 & 4250 \\
\hline 2. Loam & 5.1 & 2.3 & 29 & 40 & 29 & 2630 & 4840 \\
\hline 3. Clay loam & 4.5 & 5.4 & 47 & 28 & 22 & 6990 & 17010 \\
\hline 4. Sandy clay & 3.9 & 1.9 & 38 & 18 & 42 & 2090 & 1900 \\
\hline
\end{tabular}

The soil $\mathrm{pH}$ was measured in $0.01 \mathrm{M} \mathrm{CaCl}_{2}$ in the ratio of 1 to 2.5 . Aluminium and iron were extracted by Tamm's acid ammonium oxalate.

Table 2. Phosphorus conditions of the soils

\begin{tabular}{|c|c|c|c|c|c|c|c|}
\hline \multirow[b]{2}{*}{ Sample } & \multirow{2}{*}{$\begin{array}{l}\text { Tot. P } \\
\text { ppm }\end{array}$} & \multirow{2}{*}{$\begin{array}{l}\text { Org. P } \\
\text { ppm }\end{array}$} & \multicolumn{2}{|c|}{ Inorganic $\mathrm{P}$ ppm } & \multicolumn{2}{|c|}{ extracted by } & \multirow[t]{2}{*}{ k } \\
\hline & & & $\mathrm{NH}_{4} \mathrm{Cl}$ & $\mathrm{NH}_{4} \mathrm{~F}$ & $\mathrm{NaOH}$ & $\mathrm{H}_{2} \mathrm{SO}_{4}$ & \\
\hline 1. Silt & 860 & 240 & 2 & 62 & 164 & 312 & 232 \\
\hline 2. Loam & 1010 & 380 & 2 & 86 & 176 & 215 & 344 \\
\hline 3. Clay loam & 1570 & 570 & 3 & 120 & 528 & 205 & 820 \\
\hline 4. Sandy clay & 490 & 150 & 1 & 38 & 96 & 122 & 269 \\
\hline
\end{tabular}

The soil samples are characterized by the figures in Table 1. All the soils are acid, particularly the subsurface sample of sandy clay. The clay loam sample is richest in clay and organic matter, and it also has the highest contents of oxalate soluble iron and aluminium. It is a typical postglacial marine sediment, a so-called Litorina clay.

Data in Table 2 show that the phosphorus conditions of these samples are fairly typical of Finnish soils. The very high content of total phosphorus in the clay loam sample is likely to be due to the prolonged intensive fertilization with phosphate. Yet, because of its high content of organic matter, more than one third of its phosphorus is in organic forms. The total phosphorus content of the sandy clay is relatively low for a clay soil. 
The easily soluble inorganic phosphorus is low in all samples. In spite of the distinct acidity of the samples, the acid-soluble fraction is the largest of the fractions of inorganic phosphorus, except in the clay loam sample which is especially rich in sesquioxides. This is likely to be due to the fact that our soils are young, and a marked part of their natural phosphorus is in the form of unweathered apatite. In all samples the content of the alkali-soluble or iron bound phosphorus is higher than that of the fluoride-soluble phosphorus which is supposed to be mainly bound by aluminium.

The indicator of the phosphate sorption capacity, $\mathrm{k}$, is particularly interesting in this work. It is by far the highest in the clay loam sample which is very rich in sesquioxides. The loam sample has a k-value which is higher than the average for this kind of soil (KAILA 1963b). In the two other soils $\mathrm{k}$ is of the same order in spite of their different content of sesquioxides.

For the incubation experiment $100 \mathrm{~g}$ of air-dry soil in glass jars was mixed with $0,0.50 \mathrm{~g}$ or $1.00 \mathrm{~g} \mathrm{CaCO}_{3}$. To one half of the jars $0.400 \mathrm{~g}$ superphosphate was added and mixed thoroughly. The samples were moistened to the field capacity, and incubated at the room temperature $\left(16^{\circ}\right.$ to $\left.26^{\circ} \mathrm{C}\right)$ for eight months. They were sampled and mixed again after four months. The incubated samples were air dried at room temperature and ground.

Table 3. Phosphorus fractions in soil samples incubated for 4 months

\begin{tabular}{|c|c|c|c|c|c|c|c|c|c|c|c|}
\hline \multirow{3}{*}{ Sample } & \multirow[t]{2}{*}{$\mathrm{CaCO}_{3}$} & \multicolumn{5}{|c|}{ No superphosphate } & \multicolumn{5}{|c|}{$0.4 \%$ superphosphate } \\
\hline & & \multirow[t]{2}{*}{$\mathrm{pH}$} & \multicolumn{4}{|c|}{ P ppm extracted by } & \multirow[t]{2}{*}{$\mathrm{pH}$} & \multicolumn{4}{|c|}{ P ppm extracted by } \\
\hline & $\%$ & & $\mathrm{NH}_{4} \mathrm{C}$ & $\mathrm{NH}_{4} \mathrm{~F}$ & $\mathrm{NaOl}$ & $\mathrm{H}_{2} \mathrm{SO}_{4}$ & & $\mathrm{NH}_{4} \mathrm{Cl}$ & $\mathrm{NH}_{4} \mathrm{~F}$ & $\mathrm{NaOH}$ & $\mathrm{H}_{2} \mathrm{SO}_{4}$ \\
\hline \multirow[t]{3}{*}{ 1. Silt } & 0 & 4.6 & 1 & 68 & 174 & 307 & 4.7 & 8 & 300 & 302 & 330 \\
\hline & 0.5 & 6.7 & 2 & 74 & 151 & 335 & 6.7 & 22 & 297 & 246 & 335 \\
\hline & 1.0 & 7.3 & 3 & 77 & 128 & 331 & 7.1 & 29 & 283 & 211 & 337 \\
\hline \multirow[t]{3}{*}{ 2. Loam } & 0 & 4.6 & 2 & 101 & 194 & 215 & 4.6 & 10 & 331 & 280 & 220 \\
\hline & 0.5 & 6.1 & 3 & 112 & 191 & 223 & 6.1 & 15 & 356 & 261 & 231 \\
\hline & 1.0 & 7.1 & 5 & 108 & 151 & 251 & 6.9 & 28 & 352 & 215 & 260 \\
\hline \multirow[t]{3}{*}{ 3. Clay loam } & 0 & 4.5 & 2 & 124 & 566 & 210 & 4.6 & 4 & 253 & 760 & 224 \\
\hline & 0.5 & 5.5 & 2 & 138 & 563 & 222 & 5.5 & 5 & 297 & 745 & 231 \\
\hline & 1.0 & 6.3 & 2 & 146 & 534 & 258 & 6.2 & 6 & 318 & 682 & 268 \\
\hline \multirow[t]{3}{*}{ 4. Sandy clay } & 0 & 3.9 & 2 & 45 & 107 & 120 & 3.9 & 11 & 261 & 213 & 127 \\
\hline & 0.5 & 5.2 & 1 & 51 & 102 & 122 & 5.2 & 6 & 284 & 202 & 123 \\
\hline & 1.0 & 7.0 & 2 & 66 & 77 & 139 & 6.9 & 18 & 298 & 165 & 144 \\
\hline
\end{tabular}

\section{Results}

Results obtained when samples incubated for 4 months were analyzed, are reported in Table 3 . 
The heavier application of $\mathrm{CaCO}_{3}$ has increased the $\mathrm{pH}$-value of the soil samples up to about $\mathrm{pH} 7$, except in the clay loam soil which seems to be effectively buffered because of its high content of organic matter and clay. The incubation without lime has increased the acidity only in the loam soil which originally had the highest $\mathrm{pH}$-value of these samples. It is of interest to note that the presence of superphosphate has not caused any significant change in the acidity of the samples: only at the highest rate of liming some tendency to slightly lower $\mathrm{pH}$-numbers may be found.

A comparison of the data obtained for the samples incubated without lime and superphosphate with those for the original samples in Table 2 shows in all soils some increase in the fluoride soluble and alkali soluble phosphorus. This is likely to be due to mineralisation of organic phosphorus. The effect of liming on the native soil phosphorus appears as an increase in the fluoride soluble and acid soluble fractions with a simultaneous decrease in the alkali soluble forms.

The application of superphosphate has increased inorganic phosphorus mainly in the fluoride soluble fraction which in the silt, loam and sandy clay soils has grown larger than the alkali soluble fraction. The clay loam sample with its high content of iron bound phosphorus is again an exception. In it the alkali soluble fraction has grown more than the fluoride soluble one. In all soils, the content of alkali soluble phosphorus is the lower, the higher the application of $\mathrm{CaCO}_{3}$ was. The reverse order is found in the fractions of easily soluble and acid soluble phosphorus, and in most soils also in the fluoride soluble fraction.

The phosphorus conditions in these soil samples did not markedly change when the incubation was prolonged up to eight months. The content of fluoride soluble phosphorus tended to decrease and that of the alkali soluble form to increase both in the limed and unlimed samples, and those treated with superphosphate or incubated without it.

To obtain a clearer picture of the fate of superphosphate phosphorus in these soils, some calculations were performed. Provided that the application of superphosphate has not brought about any significant changes in the forms of native soil phosphorus, the distribution of the superphosphate phosphorus in the various fractions may be estimated on the basis of the difference between the respective data for the samples treated with superphosphate and those incubated without an application of phosphate. These results are reported in Table 4.

The increase in the various phosphorus fractions induced by the addition of superphosphate is expressed as a percentage of the total increase in the content of inorganic phosphorus extracted by the first four extractant of the CHANG and JACKSON procedure. The amount of superphosphate phosphorus applied corresponded to $340 \mathrm{ppm}$. The amount of "superphosphate phosphorus" recovered from the samples incubated for four months varied from 329 to $390 \mathrm{ppm}$, with an average of $342 \mathrm{ppm}$, and from the samples incubated for eight months from 324 to $366 \mathrm{ppm}$, averagely $345 \mathrm{ppm}$. The variation is likely to be due only to difficulties in mixing the fertilizer quite homogeneously with the soil.

The figures in Table 4 show that in the unlimed samples almost all of the superphosphate phosphorus was found in the fractions extracted by $\mathrm{NH}_{4} \mathrm{~F}$ or 
Table 4. "Superphosphate- $\mathrm{P}$ in various fractions of soil phosphorus

\begin{tabular}{|c|c|c|c|c|c|c|c|c|c|}
\hline \multirow{3}{*}{ Sample } & \multirow{3}{*}{$\begin{array}{c}\mathrm{CaCO}_{3} \\
\%\end{array}$} & \multicolumn{4}{|c|}{ Incubation period 4 months } & \multicolumn{4}{|c|}{ Incubation period 8 months } \\
\hline & & \multicolumn{8}{|c|}{ Per cent of superphosphate-P recovered by } \\
\hline & & $\mathrm{NH}_{4}$ & $\mathrm{NH}_{4} \mathrm{~F}$ & $\mathrm{TaOH}$ & $\mathrm{I}_{2} \mathrm{SO}_{4}$ & $\mathrm{NH}_{4}$ & $\mathrm{NH}_{4}$ & $\mathrm{NaOH}$ & $\mathrm{H}_{2} \mathrm{SO}_{4}$ \\
\hline \multirow[t]{3}{*}{ 1. Silt } & 0 & 2 & 59 & 33 & 6 & 2 & 61 & 31 & 6 \\
\hline & 0.5 & 6 & 66 & 28 & 0 & 7 & 61 & 28 & 4 \\
\hline & 1.0 & 8 & 64 & 26 & 2 & 10 & 58 & 27 & 5 \\
\hline \multirow[t]{3}{*}{ 2. Loam } & 0 & 2 & 70 & 26 & 2 & 3 & 64 & 32 & 1 \\
\hline & 0.5 & 4 & 73 & 21 & 2 & 5 & 67 & 23 & 5 \\
\hline & 1.0 & 7 & 72 & 19 & 2 & 10 & 66 & 21 & 3 \\
\hline \multirow[t]{3}{*}{ 3. Clay loam } & 0 & 1 & 38 & 57 & 4 & 1 & 41 & 57 & 1 \\
\hline & 0.5 & 1 & 45 & 52 & 2 & 1 & 43 & 54 & 2 \\
\hline & 1.0 & 1 & 52 & 44 & 3 & 1 & 46 & 51 & 2 \\
\hline \multirow[t]{3}{*}{ 4. Sandy clay } & 0 & 3 & 64 & 31 & 2 & 3 & 61 & 32 & 4 \\
\hline & 0.5 & 2 & 69 & 29 & 0 & 2 & 67 & 28 & 3 \\
\hline & 1.0 & 5 & 68 & 26 & 1 & 6 & 67 & 25 & 2 \\
\hline
\end{tabular}

$\mathrm{NaOH}$. In the silt, loam, and sandy clay soils, the proportion of the applied phosphorus in the former fraction is about twice as high as in the latter one. In the clay loam soil the larger part of the superphosphate phosphorus was recovered in the alkali soluble or iron bound fraction. In these acid soils a relatively low amount of the soluble phosphate added was left easily soluble or was found as the acid soluble form.

In most cases, liming increased the amount of fertilizer phosphorus in the easily soluble form. In the samples incubated for four months, also the part in the fluoride soluble fraction tends to be higher in the limed soils than in the unlimed ones. Yet, the preventive effect of lime on the retention of fertilizer phosphate as the alkali soluble form is more distinct. In the clay loam soil incubated for four months with the higher application of $\mathrm{CaCO}_{3}$ the retention pattern is changed, and the part of the fertilizer phosphorus recovered in the alkali-soluble fraction is even lower than that found in the fluoride soluble form. During the prolonged incubation, a part of the fluoride soluble "fertilizer phosphorus" appears to turn in alkali soluble form. On the other hand, some tendency to an increase in the easily soluble phosphorus content is detected in the silt and loam soil samples.

In this experiment, liming the acid soils up to about $\mathrm{pH} 7$ did not bring about any significant accumulation of the fertilizer phosphorus in the acid soluble form. The proportion of superphosphate phosphorus in this fraction varies independent of the rate of liming, and it is low in all the cases.

\section{Discussion}

Older textbooks warned against a simultaneous application of lime and superphosphate, since it was supposed that, in contact with the liming material, the 
availability of the fertilizer phosphate would decline because of the formation of relatively difficultly soluble calcium phosphates, even "tricalcium phosphate". Now, it is known that, not only in particularly acid soils, the water soluble monocalcium phosphate is rapidly sorbed by iron and aluminium compounds, and that the availability of these complexes may be poorer than that of newly precipitated calcium phosphates. Therefore, it is likely that the prevention of the contact of phosphate fertilizers with lime is not necessary. Recently, Salonen (1964) showed by pot experiments that liming of an acid soil increased the uptake of fertilizer phosphorus markedly, even when the fertilizers and the liming materials, calcium carbonate or calcium hydroxide, were thoroughly mixed with each other before the application. Although this result may have been partly due to an improvement in the growing conditions in general, the positive effect of liming on the availability of phosphorus was obvious.

PARKER and TIDMORE (1926) already found that liming increased the phosphorus content of the soil solution and water extracts of soils receiving acid phosphate. Also in the present study, the easily soluble phosphorus tended to increase with liming, particularly in soils with a lower fixing capacity. In the silt and loam samples one tenth of the "superphosphate phosphorus" was found to be easily soluble in the samples incubated for eight months with the heavier application of lime which kept the soil at about $\mathrm{pH}$ 7. In the clay loam sample with the high fixing capacity, liming had no significant effect on the keeping of the fertilizer phosphorus easily soluble.

Studies concerning the availability to plants of soil phosphorus in the other fractions of the CHANG and JACKSON procedure indicate that, usually, the fluoride soluble phosphorus appears to be the preferred source, the alkali soluble fraction will contribute to a lesser extent, the acid soluble phosphorus seems to be of a low value, and the reductant soluble and occluded forms are of no importance (HANLEY 1962, MacKenzie 1962, Smith 1965, Chu \& Chang 1966). It is likely that the same order is valid also in regard to the availability of applied phosphate retained by the soil. Therefore, it may be concluded that, in the present soil samples, the increase in the part of superphosphate phosphorus recovered by the fluoride extraction at the expense of the decrease in the part found in the alkali soluble form means that lime has improved the availability of superphosphate phosphorus.

DUNBAR and BAKER (1965) have suggested that liming results in the removal of more iron bound phosphorus with the aluminium bound fraction by the $\mathrm{NH}_{4}-\mathrm{F}$ extraction without any change in the chemical bonding from iron phosphates to aluminium phosphates. Even if this hypothesis would be valid, liming may enhance the availability of iron bound phosphate, since the bonding strength at $\mathrm{pH} 4$ to pH 5 will probably be higher than at about $\mathrm{pH} 6$ to 7 .

On the other hand, it must be remembered that one of the first reaction products of monocalcium phosphate in soil may be dicalcium phosphate, and its importance is expected to increase as the calcium content of the soil is increased (LINDSAY et al. 1959). This dicalcium phosphate is likely to be extracted mainly by the fluoride solution when in the fractionation procedure no acetic acid extraction is performed before hand (KaILA 1961, 1963a, LAverty and MacLean 1961). Some of it may be dissolved 
already by the $\mathrm{NH}_{4} \mathrm{Cl}$ extraction. Besides, Lindsay et al. (1962) found that in the presence of larger amounts of $\mathrm{CaCO}_{3}$, monocalcium phosphate will be precipitated to a greater extent as dicalcium phosphate dihydrate which is considered to be more available than the anhydrous salt into which the former will converse when only small amounts of $\mathrm{CaCO}_{3}$ are added.

In no case did liming significantly increase the very low difference between the acid soluble phosphorus values of the fertilized and unfertilized samples. This means that not even during the prolonged incubation any accumulation of the "fertilizer phosphorus" as apatite like secondary minerals did take place in the samples limed up to neutrality. Yet, the effect of liming on the native soil phosphorus appeared fairly distinctly as an increase in the acid soluble fraction. This discrepancy may be worth of further studies.

On the other hand, it is noteworthy that liming up to about $\mathrm{pH} 7$ did not prevent the retention of applied phosphorus as the alkali soluble or iron bound forms. Even in the neutral samples about one fifth to one fourth of the increase due to superphosphate was found in this fraction. In the clay loam sample rich in iron, the heavier application of lime increased the $\mathrm{pH}$ value from 4.5 to 6.3 in the samples incubated for four months, and decreased the part of alkali soluble phosphorus only from 57 per cent to 44 per cent of the "fertilizer phosphorus". During the prolonged incubation, some turning of fluoride soluble phosphorus in alkali soluble form happened: at the end of the period of eight months more than one half of the "fertilizer phosphorus" was recovered in the latter form. Thus, it seems that liming may retard the reaching of the phosphate retention pattern typical of the soil, but it does not disturb it continuously to any marked degree.

\section{$S u m m a r y$}

The effect of liming on the distribution of superphosphate phosphorus in various fractions of soil phosphorus was studied. Samples of four mineral soils $(\mathrm{pH} 3.9$ to $5.1)$ were incubated at room temperature for eight months with $0,0.5$, or 1.0 per cent $\mathrm{CaCO}_{3}$, and with 0.40 per cent superphosphate or without any phosphate application. Liming increased the soil $\mathrm{pH}$-values to $\mathrm{pH}$ 6.1-7.3. Samples were analyzed for inorganic phosphorus by the fractionation method of CHANG and JAckson.

Results obtained after an incubation period of four months showed that, both in the fertilized and unfertilized samples, liming had increased the fluoride soluble, acid soluble and easily soluble fractions, but it had decreased the alkali soluble phosphorus. These effects were generally the more distinct, the higher the application of $\mathrm{CaCO}_{3}$ had been. During the prolonged incubation, the alkali soluble fraction tended to increase at the expense of the fluoride soluble phosphorus.

The differences in the phosphorus content of various fractions in the respective fertilized and unfertilized samples showed that the nsuperphosphate phosphorus" was mainly recovered as the fluoride soluble and alkali soluble forms, the relative amount of the latter being the lower the heavier the liming had been. Yet, even

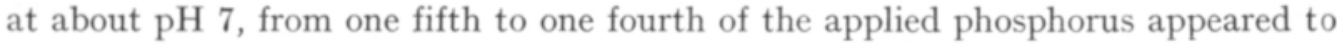


be sorbed by iron compounds and ocurred in the alkali soluble fraction. The sum of the proportions of easily soluble and fluoride soluble phosphorus increased with liming.

The small parts of fertilizer phosphorus recovered in the acid soluble form did not depend on the rate of liming. Thus, even at $\mathrm{pH} 7$, no significant turning of superphosphate phosphorus in difficultly soluble apatite like secondary calcium phosphates could be detected.

The effect of liming on the availability of the fertilizer phosphorus and on the phosphate retention pattern of the soil, was discussed.

\section{REFERENCES}

Chang, S. C. \& Jackson, M. L. 1957. Fractionation of soil phosphorus. Soil Sci. 84: 133 - 144.

Chu, W. K. \& Chang, S. C. 1966. Surface activity of inorganic soil phosphorus. Ibid. 101: $459-464$.

DUnBar, A. D. \& BAKER, D. E. 1965. Use of isotopic dilution in a study of inorganic phosphorus fractions from different soils. Soil Sci. Soc. Amer. Proc. 29: 259- 262.

HANLEY, K. 1962. Soil phosphorus forms and their availability to plants. Irish J. Agr. Res. 1: 192 - 193.

Karla, A. 1961. Effect of incubation and liming on the phosphorus fractions in soil. J. Sci. Agric. Soc. Finland 33: $185-193$.

- 1962. Determination of total organic phosphorus in samples of mineral soils. Ibid. $34: 187-196$.

$-1963 \mathrm{a}$. Fertilizer phosphorus in various fractions of soil phosphorus. Ibid. $35: 36-46$.

- 1963b. Dependence of the phosphate sorption capacity on the aluminium and iron in Finnish soils. Ibid. 35 : $165-177$.

- 1965a. The fate of water-soluble phosphate applied to some mineral soils. Ibid. $37: 104-115$.

$-1965 \mathrm{~b}$. Effect of liming on the mobilization of soil phosphorus. Ibid. $37: 243-254$.

Lindsay, W. L. \& Frazier, A. W. \& Stephenson, H. F. 1962. Identification of reaction products from phosphate fertilizers in soils. Soil Sci. Soc. Amer. Proc. 26: 446-452.

- - \& Lehr, J. R. \& Stephenson, H. F. 1959. Nature of the reactions of monocalcium phosphate monohydrate in soils: III. Ibid. $23: 342-345$.

MacKenzie, A. F. 1962. Inorganic soil phosphorus fractions of some Ontario soils as studied using isotopic exchange and solubility criteria. Canad. J. Soil Sci. 42: $150-156$.

Muir, J. W. 1952. The determination of total phosphorus in soil. Analyst 77: 313-317.

PARKer, F. W. \& TIDmore, J. W. 1926. The influence of lime and phosphate fertilizers on the phosphorus content of the soil solution and soil extracts. Soil Sci. 21: $425-441$.

SALONEN, M. 1964. Kalkin ja fosforilannoitteiden samanaikaisen käytön vaikutuksesta niiden tehoon. (Summary: The effect of simultaneous application of lime and phosphate fertilizers on their efficiency.) Ann. Agric. Fenniae 3: 287-295.

Sмгтн, A. N. 1965. The supply of soluble phosphorus to the wheat plant from inorganic soil phosphorus. Plant and Soil 22: $314-316$.

SELOSTUS:

\section{KALKITUKSEN VAIKUTUKSESTA SUPERFOSFAATIN FOSFORIN PIDÄTTYMISEEN ERÄISSÄ KIVENNÄISMAISSA}

ARMi KAILA

Yliopiston maanviljelyskemian laitos, Viikki

Muhituskokein seurattiin kalsiumkarbonaatin kanssa neljään happamaan kivennäismaahan sekoitetun superfosfaatin fosforin jakautumista maan eri fosforifraktioihin. 
Todettiin, että kalkitus lisäsi sekä lannoitetuissa että lannoittamattomissa näytteissä fluoridiin, rikkihappoon ja ammoniumkloridiin liukenevan fosforin määrää sekä vähensi emäkseen uuttuneen fosforin osuutta. Vaikutus oli sitä selvempi, mitä voimakkaampi kalkitus oli annettu. Erot neljä ja kahdeksan kuukautta muhitetuissa näytteissä olivat verraten pienet: muhitusajan pidentyessä fluoridiin uuttunutta fosforia näytti siirtyvän emäkseen liukenevaan fraktioon.

Samaa kalkitusastetta edustavien lannoitettujen ja lannoittamattomien näytteiden vastaavien fraktioiden erotukset osoittivat, että suurin osa ssuperfosfaatin fosforista oli pidättynyt fluoridiin ja emäkseen liukeneviin fraktioihin. Jälkimmäisen osuus oli sitä pienempi, mitä enemmän kalkkia oli annettu. Kuitenkin vielä $\mathrm{pH} 7$ :n tienoilla $1 / 5$ - 1/4 lannoitteen fosforista näytti olevan raudan yhdisteiden sitomaa eli emäkseen liukenevaa. Helposti liukenevan ja fluoridiin liukenevan fosforin yhteisosuus kasvoi kalkituksen mukana.

Vain varsin pieni osa lannoitefosforista näytti joutuneen happoon liukenevaan fraktioon, eikä tämä määrä riippunut kalkituksen tehokkuudesta. Ei edes $\mathrm{pH} 7$ :ssä voitu todeta superfosfaatin fosforin pidättymistä apatiitin kaltaisina sekundäärisinä mineraaleina. 